\title{
Total Quality Management of Information System for Quality Assessment of Pesantren Using Fuzzy-SERVQUAL
}

\author{
Arbiati Faizah $^{1, *}$, Wahyul Amien Syafei ${ }^{2}$, and R. Rizal Isnanto ${ }^{3}$ \\ ${ }^{1}$ Master of Information System, School of Postgraduate Studies, Diponegoro University, Semarang - Indonesia 50242 \\ ${ }^{2}$ Department of Electronic Engineering, Faculty of Engineering, Diponegoro University, Semarang - Indonesia 50275 \\ ${ }^{3}$ Department of Computer System, Faculty of Engineering, Diponegoro University, Semarang - Indonesia 50275
}

\begin{abstract}
This research proposed a model combining an approach of Total Quality Management (TQM) and Fuzzy method of Service Quality (SERVQUAL) to asses service quality. TQM implementation was as quality management orienting on customer's satisfaction by involving all stakeholders. SERVQUAL model was used to measure quality service based on five dimensions such as tangible, reliability, responsiveness, assurance, and empathy. Fuzzy set theory was to accommodate subjectivity and ambiguity of quality assessment. Input data consisted of indicator data and quality assessment aspect. Input data was, then, processed to be service quality assessment questionnaires of Pesantren by using Fuzzy method to get service quality score. This process consisted of some steps as follows : inputting dimension and questionnaire data to data base system, filling questionnaire through system, then, system calculated fuzzification, defuzzification, gap of quality expected and received by service receivers, and calculating each dimension rating showing quality refinement priority. Rating of each quality dimension was, then, displayed at dashboard system to enable users to see information. From system having been built, it could be known that tangible dimension had the highest gap, -0.399 , thus it needs to be prioritized and gets evaluation and refinement action soon
\end{abstract}

\section{Introduction}

Pesantren is the oldest education institution in Indonesia, in which this institution takes a part in giving education especially religion education to society [1]. Pesantren institution is demanded to implement quality control system to ensure performance achievement in product or merit service made.

Information system of Total Quality Management (TQM) is used as a tool to support management process so that the decision makers can arrange planning and make decision more efficiently [2]. Information system of TQM also can be used as benchmarks based on customers' satisfaction on merit service given by education institution. Customers meant in this case are those having relation with education institution such as students, teachers, parents, and society. Customers' satisfication on merit service quality can be measured by using SERVQUAL (Service Quality) model. This model measures service quality using five different dimensions which can be admitted as indicators making quality service received by customers [3].

In service satisfaction analysis, customers' judgment subjectivity has uncertain score of information characteristic given. Fuzzy set is used as representation and information processing influenced by some uncertainties because of natural language use. Fuzzy set can be used as a tool to calculate linguistic data and change it to be a numeric format so it is easily manipulated by computer [4].

Based on how important TQM implementation is in Pesantren, this research was hoped to be a solution in building information system of total quality management to measure achievement of pesantren quality by using fuzzy SERVQUAL. This system was applied online, so it enabled the decision makers to evaluate and make decision about quality refinement efficiently.

\section{Total Quality Management (TQM) of Pesantren}

In Pesantren education context, the starting point of quality is the strengthening of vision and mission directed to customers' satisfaction; it is satisfaction of education merit users (students' parents, working world) [5]. Criteria of qualified Pesantren are as follows:

1. Safe and orderly education environment.

2. Clear vision, mission and quality target forming.

3. Reliable education leadership.

4. High achievement expectation and output.

5. Qualification development and improvement.

6. Effective and efficient learning evaluation.

7. Interaction among institution, parents and society [6].

TQM is as an integrated organization strategy to increase qualified product and service as a helper or a solution for various problems faced by an organization,

Corresponding author: arbiati f(astudent.undip.ac.id 
including organization performance improvement. Four main principles in TQM are as follows:

1. Customers' satisfaction.

2. Respect to everyone.

3. Fact based management.

4. Continuous refinement.

Quality management system always has something to do with cycle concept of PDCA (Plant-Do-Check_Act). Fig. 1 shows PDCA cycle in continuous refinement.

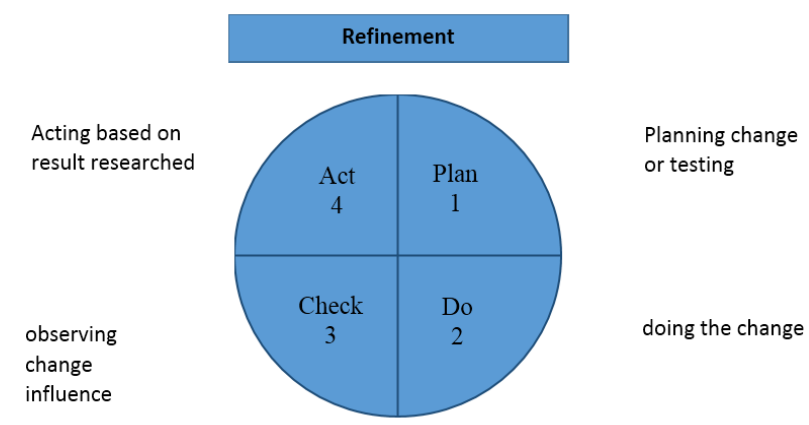

Fig. 1. PDCA Cycle [7]

The success benchmarks of quality management in Pesantren are measured from internal and external customers' satisfaction levels. Pesantren is said to be successful if they can give service as customers' expectation. Customers' satisfaction indicators on service given by Pesantren are as follows:

1. Students are satisfied with service of Pesantren.

2. Parents feel satisfied with service given to their children.

3. Users or receivers of alumni are satisfied because of receiving alumni with high quality and suitable with their expectation

4. Teachers and staffs are satisfied with service given by Pesantren [8].

\section{Service Quality (SERVQUAL)}

Quality in merit organization is a measurement of achievement range of service given to fulfill customers' expectation. Model of SERVQUAL is used to measure service quality received by customers. Merit quality dimensions are used in measuring service merit quality. The service quality dimensions consist of tangible, reliability, responsiveness, assurance, and empathy. The measuring of merit quality using model of SERVQUAL consists of score gap given by customers for statements relating to expectation and perception about merit received by customers. The calculation of score gap between expectation and perception using formula 1 .

$$
S Q=\sum_{i=1}^{k}\left(P_{i}-E_{i}\right)
$$

The assessment of service quality is calculated based on the number of attribute $k$. Then, it is continued by calculating score differences from perception scores of each attribute $\left(P_{i}\right)$ and expectation scores of each attribute $\left(E_{i}\right)$.

\section{Fuzzy Set}

Fuzzy compilation theory gives tool to present uncertainty and also becomes a good tool for uncertainty modeling relating to vagueness, incorrectness and lack of information about certain elements of problem faced. The power becoming base of Fuzzy compilation theory is that the use of linguistic variable is better than quantitative variable to present concept which is not precisive. Fuzzy compilation is a set containing elements having different member degrees and are very different from classic set (crisp).

Membership function can be expressed as triangular function, gaussian function, or trapeziodal function. Membership function on triangular curve can be expressed by using Triangular Fuzzy Number (TFN). TFN is fuzzy compilation expressed in the interval form used to represent subjective judgment of customers. Triangular curve is basically combination of lines shown in Fig. 2.

Membership function :

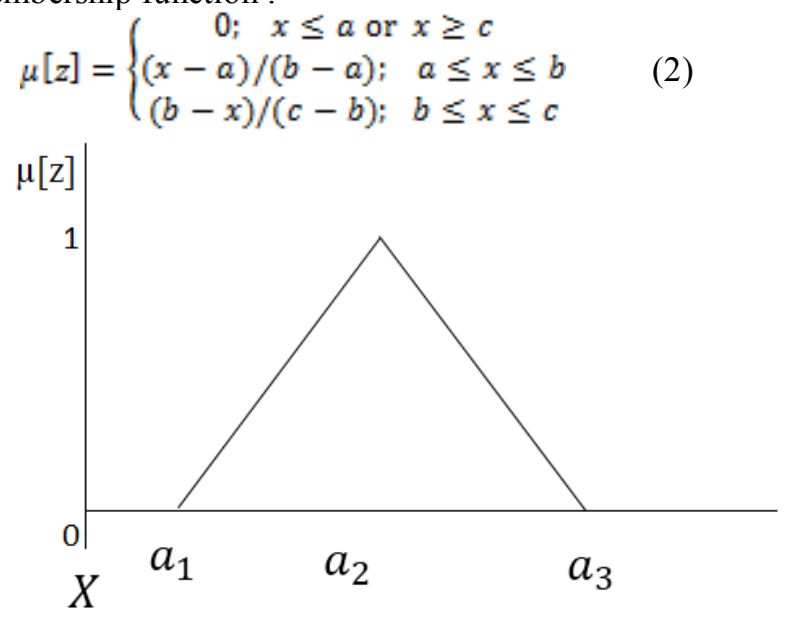

Fig. 2. Triangular curve [9]

Calculation of fuzzification on service quality assessment can be done by looking for score of $a_{1}, a_{2}, a_{3}$ for each aspect based on formula 3, 4, 5 [10].

Lower limit $\left(\mathrm{a}_{1}\right)=$

$\frac{b_{i 1 * n_{1}+} b_{i 1} * n_{2+b_{i 2}} n_{3+}+\cdots+b_{i(k-1)}{ }^{*} n_{k}}{n_{1+} n_{2+n_{3}+\cdots \ldots+n_{k}}}$

Middle Score $\left(\mathrm{a}_{2}\right)=$

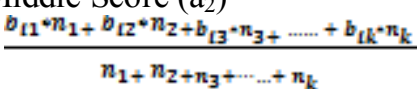

Upper limit $\left(\mathrm{a}_{3}\right)=$

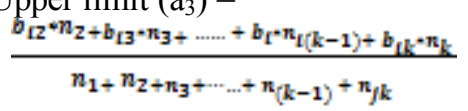

The next step is defuzzification. Defuzzification process is done to get a single score by using formula of Mean of the maximum as follows:

Deffuzification $=\left(\left(a_{3}-a_{1}\right)+(a 2-a 1)\right) / 3+a 1$ 


\section{Methodology}

This research had some steps which had to be done in information system built. Those steps consisted of determining input, storing, processing, and output. Design form of system modelled is appropriate with this research purpose; which was building quality assessment system using method of fuzzy-SERVQUAL. In Pesantren, variables involved in quality assessment are : quality assurance unit, tutors, teachers/ustadz, staffs and pengasuh. Assessment indicators come from work planning and program of quality assurance. Attribute of questions are arranged from those indicators and classified into dimensions of SERVQUAL shown in picture 3 .

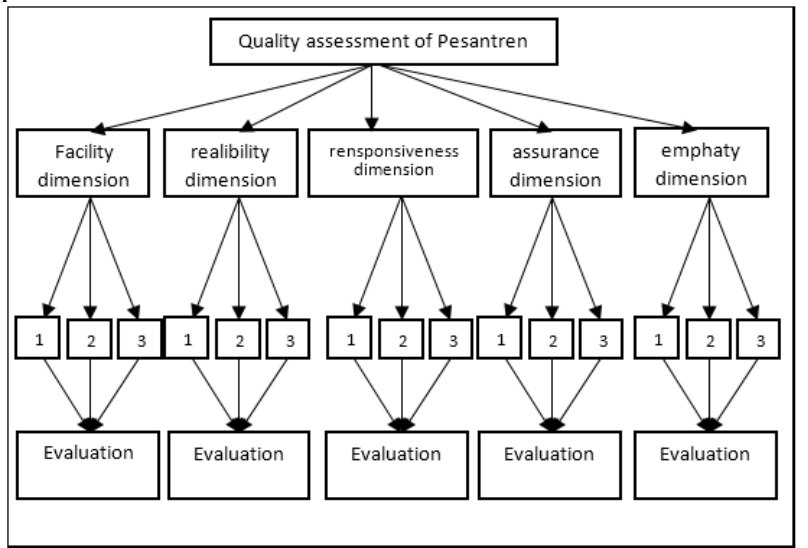

Picture 2. SERVQUAL Hierarchy Model of Pesantren quality assessment

Attribute of questions are used as criteria of quality assessment between expectation and perception. Perception meant in this discussion is customers' satisfaction on merit or service given by Pesantren. Input system consists of quality assessment by merit users. Attributes of questions of each dimension are shown in table 1. Result of this quality assessment is then stored at database. Assessment data got is then processed by using fuzzy method.

Calculation processes consist of fuzzification, and defuzzification of triangular fuzzy number. Fuzzy compilation data taken for fuzzification calculation were statement data on questionnaire about fact and expectation as shown in table 2.

Fuzzification calculation on service quality assessment can be done by looking for scores of a,b,c of each attribute by using formula $3,4,5$. The next step is defuzzification. Defuzzification process is done to get single score by using formula 6 . After single score is got, system, then, calculates gaps of each criteria based on indicators and quality of scores given by respondents. Output is resulted from this process in the form of result data of quality achievement assessment of Pesantren. Those data can be used as materials of dimension evaluation and to know which aspect must be improved.
Table 1. Attributes and variables in SERVQUAL dimension

\begin{tabular}{|c|c|c|}
\hline $\begin{array}{l}\text { Dime } \\
\text { nsion } \\
\text { s }\end{array}$ & Attributes & $\begin{array}{l}\text { Vari } \\
\text { ables }\end{array}$ \\
\hline \multirow{5}{*}{$\begin{array}{l}\text { Tangi } \\
\text { ble }\end{array}$} & $\begin{array}{l}\text { Completeness and readiness in } \\
\text { teaching and learning process }\end{array}$ & $\mathrm{X}_{11}$ \\
\hline & Availability of clean eating place & $\mathrm{X}_{12}$ \\
\hline & $\begin{array}{l}\text { Every day cleanliness and comfort } \\
\text { of Pesantren }\end{array}$ & $\mathrm{X}_{13}$ \\
\hline & $\begin{array}{l}\text { Spatial arrangement in library and } \\
\text { other supporting facilities }\end{array}$ & $\mathrm{X}_{14}$ \\
\hline & $\begin{array}{l}\text { Availability and capacity of parking } \\
\text { area }\end{array}$ & $\mathrm{X}_{15}$ \\
\hline \multirow{5}{*}{$\begin{array}{l}\text { Respo } \\
\text { nsive } \\
\text { ness }\end{array}$} & $\begin{array}{l}\text { Teachers' capability which is } \\
\text { professional and right }\end{array}$ & $X_{21}$ \\
\hline & $\begin{array}{l}\text { Clear and correct explanation when } \\
\text { there is students' or their parents' } \\
\text { question }\end{array}$ & $X_{22}$ \\
\hline & $\begin{array}{l}\text { Teachers' good capabilities in } \\
\text { delivering material }\end{array}$ & $X_{23}$ \\
\hline & Security always works well & $\mathrm{X}_{24}$ \\
\hline & $\begin{array}{l}\text { Builders always do their tasks as } \\
\text { their capacities }\end{array}$ & $X_{25}$ \\
\hline \multirow{5}{*}{$\begin{array}{l}\text { Assur } \\
\text { ance }\end{array}$} & $\begin{array}{l}\text { Teachers' knowledge and } \\
\text { capabilities in teaching }\end{array}$ & $X_{31}$ \\
\hline & $\begin{array}{l}\text { Other skills of teachers and staffs in } \\
\text { working }\end{array}$ & $X_{32}$ \\
\hline & Polite and friendly service & $\mathrm{X}_{33}$ \\
\hline & $\begin{array}{l}\text { Safety and comfort in teaching and } \\
\text { learning process }\end{array}$ & $\mathrm{X}_{34}$ \\
\hline & $\begin{array}{l}\text { Students get assurance of caring } \\
\text { facilities in Pesantren clinic }\end{array}$ & $X_{35}$ \\
\hline \multirow{5}{*}{$\begin{array}{l}\text { Emph } \\
\text { aty }\end{array}$} & $\begin{array}{l}\text { The same service is given without } \\
\text { considering social status and others }\end{array}$ & $X_{41}$ \\
\hline & $\begin{array}{l}\text { Staffs always give friendly and } \\
\text { polite service to students }\end{array}$ & $X_{42}$ \\
\hline & $\begin{array}{l}\text { There is communication among } \\
\text { staffs, builders, and boards }\end{array}$ & $\mathrm{X}_{43}$ \\
\hline & $\begin{array}{l}\text { Boards always watch on the } \\
\text { running of Pesantren program }\end{array}$ & $\mathrm{X}_{44}$ \\
\hline & $\begin{array}{l}\text { Boards pay attention to program } \\
\text { service of Pesantren }\end{array}$ & $\mathrm{X}_{45}$ \\
\hline \multirow{5}{*}{$\begin{array}{l}\text { Relia } \\
\text { bility }\end{array}$} & $\begin{array}{l}\text { Discipline of time delivering } \\
\text { material as what is determined on } \\
\text { the schedule }\end{array}$ & $\mathrm{X}_{51}$ \\
\hline & Easy administration service & $\mathrm{X}_{52}$ \\
\hline & $\begin{array}{l}\text { The improving of students' abilities } \\
\text { in using foreign languages (Arabic } \\
\text { and English) }\end{array}$ & $X_{53}$ \\
\hline & $\begin{array}{l}\text { Technology based administration } \\
\text { service }\end{array}$ & $\mathrm{X}_{54}$ \\
\hline & $\begin{array}{l}\text { Guidelines of ethic codes in } \\
\text { Pesantren environment (students, } \\
\text { teachers, staffs, builders) }\end{array}$ & $\mathrm{X}_{55}$ \\
\hline
\end{tabular}


Table 2. Fuzzy set Data set on quality assessment variables

\begin{tabular}{|l|l|l|}
\hline Variable & Statement & $\begin{array}{l}\text { Membership } \\
\text { Function }\end{array}$ \\
\hline \multirow{4}{*}{$\begin{array}{l}\text { Expectatio } \\
\mathrm{n}\end{array}$} & Very unimportant & $(0,0,2)$ \\
\cline { 2 - 3 } & Unimportant & $(0,2,4)$ \\
\cline { 2 - 3 } & Important enough & $(2,4,6)$ \\
\cline { 2 - 3 } & Important & $(4,6,8)$ \\
\cline { 2 - 3 } Perception/ $/$ & Very Important & $(6,8,8)$ \\
\hline \multirow{4}{*}{ Satisfaction } & Very Bad & $(0,0,2)$ \\
\cline { 2 - 3 } & Bad & $(0,2,4)$ \\
\cline { 2 - 3 } & Good Enough & $(2,4,6)$ \\
\cline { 2 - 3 } & Good & $(4,6,8)$ \\
\cline { 2 - 3 } & Very Good & $(6,8,8)$ \\
\hline
\end{tabular}

\section{Result and Discussion}

Implementation of total quality management of information system consisted of three user levels. In this research, system users cover: administrator, quality control, caregiver, teachers, staffs, and students.

1. Level one : administrator and quality control In this level, users have access rights to manage all contents existing in system and see report of quality assessment result from users.

2. Level two : pengasuh

Pengasuh is as top management and decision maker. In this level, user has access right to see planning and quality aspects as well as report of quality assessment result.

3. Level three : teachers/ustadz, staffs, and students

As the receivers of merit service given by Pesantren, this level has access to fill questionnaire list on the system and see a whole assessment result.

In this research, quality assessment was done by 100 respondents consisting of teachers/ustadz, staffs and students. Assessment was done by filling questionnair forms about users' perception and expectation on merit service given by Pesantren. Result of this assessment was then processed by system by using fuzzy method. Calculation result of quality assessment by users is shown in table 3 and 4.

Table 3. Result of perception fuzzification and defuzzification

\begin{tabular}{|c|c|c|c|l|}
\hline \multirow{2}{*}{$\begin{array}{l}\text { Variabl } \\
\text { e }\end{array}$} & \multicolumn{3}{|c|}{ Fuzzification } & \multirow{2}{*}{$\begin{array}{l}\text { Defuzzifica- } \\
\text { tion }\end{array}$} \\
\cline { 2 - 4 } & $\mathbf{a}$ & $\mathbf{b}$ & $\mathbf{c}$ & 6.137 \\
\hline $\mathrm{X}_{11}$ & 4.392 & 6.392 & 7.629 & 6.385 \\
\hline $\mathrm{X}_{12}$ & 4.722 & 6.722 & 7.711 & 6.385 \\
\hline $\mathrm{X}_{13}$ & 4.887 & 6.887 & 7.835 & 6.536 \\
\hline $\mathrm{X}_{14}$ & 4.598 & 6.598 & 7.711 & 6.302 \\
\hline $\mathrm{X}_{15}$ & 4.309 & 6.309 & 7.670 & 6.096 \\
\hline $\mathrm{X}_{21}$ & 5.010 & 7.010 & 7.835 & 6.619 \\
\hline $\mathrm{X}_{22}$ & 4.598 & 6.598 & 7.670 & 6.289 \\
\hline $\mathrm{X}_{23}$ & 4.845 & 6.845 & 7.711 & 6.467 \\
\hline $\mathrm{X}_{24}$ & 4.309 & 6.309 & 7.546 & 6.055 \\
\hline $\mathrm{X}_{25}$ & 4.722 & 6.722 & 7.670 & 6.371 \\
\hline $\mathrm{X}_{31}$ & 4.887 & 6.887 & 7.794 & 6.522 \\
\hline $\mathrm{X}_{32}$ & 4.928 & 6.928 & 7.876 & 6.577 \\
\hline $\mathrm{X}_{33}$ & 5.052 & 7.052 & 7.753 & 6.619 \\
\hline
\end{tabular}

\begin{tabular}{|l|l|l|l|l|}
\hline$X_{34}$ & 4.722 & 6.722 & 7.794 & 6.412 \\
\hline$X_{35}$ & 5.175 & 7.175 & 7.918 & 6.756 \\
\hline$X_{41}$ & 4.433 & 6.392 & 7.629 & 6.151 \\
\hline$X_{42}$ & 4.515 & 6.515 & 7.629 & 6.220 \\
\hline$X_{43}$ & 4.474 & 6.474 & 7.629 & 6.192 \\
\hline$X_{44}$ & 4.763 & 6.763 & 7.835 & 6.454 \\
\hline$X_{45}$ & 4.928 & 6.928 & 7.835 & 6.564 \\
\hline$X_{51}$ & 4.598 & 6.598 & 7.670 & 6.289 \\
\hline$X_{52}$ & 4.722 & 6.722 & 7.794 & 6.412 \\
\hline$X_{53}$ & 3.814 & 5.773 & 7.175 & 5.588 \\
\hline$X_{54}$ & 4.515 & 6.515 & 7.711 & 6.247 \\
\hline$X_{55}$ & 4.804 & 6.804 & 7.876 & 6.495 \\
\hline
\end{tabular}

Table 5. Result of expectation fuzzification and deffuzification

\begin{tabular}{|c|c|c|c|c|}
\hline \multirow[t]{2}{*}{ Variable } & \multicolumn{3}{|c|}{ Fuzzification } & \multirow{2}{*}{$\begin{array}{l}\text { Deffuzifica } \\
\text { tion }\end{array}$} \\
\hline & $\mathbf{a}$ & b & c & \\
\hline $\mathrm{X}_{11}$ & 5.155 & 7.155 & 7.959 & 6.756 \\
\hline $\mathrm{X}_{12}$ & 5.361 & 7.361 & 7.959 & 6.893 \\
\hline $\mathrm{X}_{13}$ & 5.443 & 7.443 & 7.959 & 6.948 \\
\hline $\mathrm{X}_{14}$ & 4.680 & 6.680 & 7.773 & 6.378 \\
\hline $\mathrm{X}_{15}$ & 4.784 & 6.784 & 7.856 & 6.474 \\
\hline $\mathrm{X}_{21}$ & 5.320 & 7.320 & 7.959 & 6.866 \\
\hline $\mathrm{X}_{22}$ & 5.216 & 7.216 & 7.814 & 6.749 \\
\hline $\mathrm{X}_{23}$ & 5.175 & 7.175 & 7.897 & 6.749 \\
\hline$X_{24}$ & 4.804 & 6.804 & 7.753 & 6.454 \\
\hline$X_{25}$ & 5.072 & 7.072 & 7.897 & 6.680 \\
\hline$X_{31}$ & 5.320 & 7.320 & 7.959 & 6.866 \\
\hline $\mathrm{X}_{32}$ & 5.155 & 7.155 & 7.959 & 6.756 \\
\hline$X_{33}$ & 5.278 & 7.278 & 7.876 & 6.811 \\
\hline $\mathrm{X}_{34}$ & 5.237 & 7.237 & 7.959 & 6.811 \\
\hline$X_{35}$ & 5.485 & 7.485 & 7.959 & 6.976 \\
\hline$X_{41}$ & 4.948 & 6.887 & 7.773 & 6.536 \\
\hline $\mathrm{X}_{42}$ & 4.742 & 6.742 & 7.711 & 6.399 \\
\hline $\mathrm{X}_{43}$ & 4.680 & 6.680 & 7.814 & 6.392 \\
\hline $\mathrm{X}_{44}$ & 4.969 & 6.969 & 7.897 & 6.612 \\
\hline $\mathrm{X}_{45}$ & 4.948 & 6.948 & 7.856 & 6.584 \\
\hline $\mathrm{X}_{51}$ & 5.113 & 7.113 & 7.876 & 6.701 \\
\hline $\mathrm{X}_{52}$ & 5.052 & 7.052 & 8.000 & 6.701 \\
\hline $\mathrm{X}_{53}$ & 4.557 & 6.557 & 7.546 & 6.220 \\
\hline $\mathrm{X}_{54}$ & 4.784 & 6.784 & 7.918 & 6.495 \\
\hline $\mathrm{X}_{55}$ & 5.052 & 7.052 & 7.876 & 6.660 \\
\hline
\end{tabular}

Deffuzification result shown in table 4 is higher than deffuzification result shown in table 3 . It shows that expectation score is higher than perception score. This result shows that receivers of merit service want something better than this condition. Expectation score which is higher than perception score causes the existence of negative gap. It shows that the real condition has not fulfilled expectation wanted by merit service receivers yet in Pesantren. So there must be evaluation and follow up from decision makers.

Table 5. Gap Score of SERVQUAL

\begin{tabular}{|c|l|l|l|}
\hline Variable & $\begin{array}{c}\text { Perception } \\
\text { Score }\end{array}$ & $\begin{array}{c}\text { Expecta- } \\
\text { tion Score }\end{array}$ & Gap \\
\hline $\mathrm{X}_{11}$ & 6.137 & 6.756 & -0.619 \\
\hline $\mathrm{X}_{12}$ & 6.385 & 6.893 & -0.509 \\
\hline $\mathrm{X}_{13}$ & 6.536 & 6.948 & -0.412 \\
\hline $\mathrm{X}_{14}$ & 6.302 & 6.378 & -0.076 \\
\hline
\end{tabular}




\begin{tabular}{|c|l|l|l|}
\hline Variable & $\begin{array}{c}\text { Perception } \\
\text { Score }\end{array}$ & $\begin{array}{c}\text { Expecta- } \\
\text { tion Score }\end{array}$ & Gap \\
\hline $\mathrm{X}_{15}$ & 6.096 & 6.474 & -0.378 \\
\hline $\mathrm{X}_{21}$ & 6.619 & 6.866 & -0.247 \\
\hline $\mathrm{X}_{22}$ & 6.289 & 6.749 & -0.460 \\
\hline $\mathrm{X}_{23}$ & 6.467 & 6.749 & -0.282 \\
\hline $\mathrm{X}_{24}$ & 6.055 & 6.454 & -0.399 \\
\hline $\mathrm{X}_{25}$ & 6.371 & 6.680 & -0.309 \\
\hline $\mathrm{X}_{31}$ & 6.522 & 6.866 & -0.344 \\
\hline $\mathrm{X}_{32}$ & 6.577 & 6.756 & -0.179 \\
\hline $\mathrm{X}_{33}$ & 6.619 & 6.811 & -0.192 \\
\hline $\mathrm{X}_{34}$ & 6.412 & 6.811 & -0.399 \\
\hline $\mathrm{X}_{35}$ & 6.756 & 6.976 & -0.220 \\
\hline $\mathrm{X}_{41}$ & 6.151 & 6.536 & -0.385 \\
\hline $\mathrm{X}_{42}$ & 6.220 & 6.399 & -0.179 \\
\hline $\mathrm{X}_{43}$ & 6.192 & 6.392 & -0.199 \\
\hline $\mathrm{X}_{44}$ & 6.454 & 6.612 & -0.158 \\
\hline $\mathrm{X}_{45}$ & 6.564 & 6.584 & -0.021 \\
\hline $\mathrm{X}_{51}$ & 6.289 & 6.701 & -0.412 \\
\hline $\mathrm{X}_{52}$ & 6.412 & 6.701 & -0.289 \\
\hline $\mathrm{X}_{53}$ & 5.588 & 6.220 & -0.632 \\
\hline $\mathrm{X}_{54}$ & 6.247 & 6.495 & -0.247 \\
\hline $\mathrm{X}_{55}$ & 6.495 & 6.660 & -0.165 \\
\hline & & & \\
\hline
\end{tabular}

Table 5 shows gap score of each attribute of perception and expectation. The biggest gap is on variable $\mathrm{X}_{53}$ which is the improving of students' abilities in using foreign languages, with gap score of -0.632 . From this result, it can be known that students' foreign language abilities need to be improved and developed. Meanwhile, the smallest gap score is on variable $\mathrm{X}_{45}$; which is the attentions of the boards to program service of Pesantren. It means that service given by Pesantren has already been good even though it is very small and there is still gap.

Score of each attribute is then classified into each dimension to get SERVQUAL score for each dimension. This SERVQUAL score is then ranked to know which dimension have the highest gap level so that it can become material for quality refinement evaluation in the next. SERVQUAL score of each dimension is shown in table 6 .

Table 6. SERVQUAL score of each quality assessment dimension

\begin{tabular}{|l|l|l|l|l|}
\hline $\begin{array}{l}\text { Dimensi } \\
\text { on }\end{array}$ & $\begin{array}{l}\text { Percepti } \\
\text { on Score }\end{array}$ & $\begin{array}{l}\text { Expecta- } \\
\text { tion } \\
\text { Score }\end{array}$ & GAP & Rank \\
\hline Tangible & 6.690 & 6.291 & -0.399 & 1 \\
\hline $\begin{array}{l}\text { Responsi } \\
\text { veness }\end{array}$ & 6.700 & 6.360 & -0.340 & 3 \\
\hline $\begin{array}{l}\text { Assuran } \\
\text { ce }\end{array}$ & 6.844 & 6.577 & -0.267 & 4 \\
\hline Emphaty & 6.504 & 6.316 & -0.188 & 5 \\
\hline $\begin{array}{l}\text { Reliabi } \\
\text { lity }\end{array}$ & 6.555 & 6.206 & -0.349 & 2 \\
\hline
\end{tabular}

\section{GAP of Quality Assessment of Each Dimension}

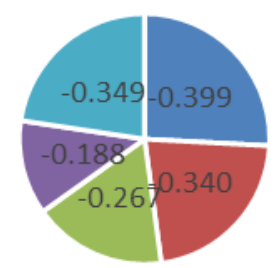

$$
\begin{array}{ll}
\text { - Tangible } & \text { - Responsiveness }=\text { Assurance } \\
\text { - Emphaty } & \text { neliability }
\end{array}
$$

Fig. 3. GAP of each dimension

Fig. 3 tells that gap score of each dimension is less than 0 , it means that expectation of service given is still higher than perception received by users. From those five dimensions, tangible dimension has the highest gap ; which is -0.399 , and empathy dimension has the smallest gap, which is -0.188 . It shows that there is a need to do refinement of service related to attributes existing on tangible dimension to fulfill standard of quality expected. The gap score of each dimension is shown in picture 3 .

\section{Conclusion}

Total quality management of information system can be implemented to assess Pesantren quality based on merit service given. Assessment of quality given is based on dimensions existing on SERVQUAL, such as tangible, reliability, responsiveness, assurance, and empathy dimensions, then their attributes are arranged for each dimension. Assesment is processed by using fuzzy method to get the certainty of score. From research result, it can be got that the highest gap score was on attribute of the improving of students' foreign language abilities, with the gap score of -0.632 , meanwhile for assessment of each dimension, tangible dimension has the highest gap, which is $\mathrm{r}-0.399$. The result got is hoped to be recommendation for decision makers to evaluate Pesantren quality refinement.

\section{References}

1. Akhiruddin. Lembaga Pendidikan Islam Nusantara. Jurnal Tarbiya, 195-219.( 2015)

2. S. Srima, P. Wannapiroon, \& P. Nilsook. Procedia Social and Behavioral Sciences Vol. 174. 2160 2165, (2014)

3. E. Akhlaghi, S. Amini, \& H. Akhlaghi. Procedia Social and Behavioral Sciences, Vol. 46. 5285 5289, (2012)

4. T. Lupo, Journal of Expert Systems with Applications Vol. 40. 7096-7110, (2013)

5. Z. Dali, Jurnal At-Ta'lim, Vol.12 No.1, (2013) 
6. M.K. Fadillah, Jurnal At-Ta'lim Vol.10 No.1,( 2015)

7. M.N. Nasution, Manajemen Mutu Terpadu (Total Quality Management), Ghalia Indonesia, Bogor. (2015

8. F. Mubarak, Jurnal Management of Education Vol. 1, 10-18.( 2015)
9. C.J. Chien, H.H. Tsai, Fuzzy and Set Systems Journal. Vol. 116, 289-300, (2000)

10. D.P. Maruvada, R.S. Bellamkonda, International Journal of Innovation, Management and Technology, Vol. 1, 478-482, (2010). 